\title{
Beyond the Pragmatic and the Liminal: Culturally and Linguistically Diverse Students Code-Switching in Early-Years Classrooms
}

Luigi Iannacci

This article examines the code-switching (CS) practices of culturally and linguistically diverse (CLD) young children in kindergarten and grade 1 classrooms. The author argues that their use of CS went beyond relief of psycholinguistic stress or coping with liminality (sense of living between two languages and cultures). Through several narratives constructed using ethnographic data, the author explores CLD students' use of CS to respond to the sociolinguistic and sociopolitical dynamics that they encountered in their early-years classrooms. CS enabled students to address their language and literacy needs, assert their identities, and defy subtractive and assimilative orientations that they experienced with respect to lack of incorporation of their first languages. Further, data affirm Cummins' (2001) assertion that students do not passively accept dominantgroup attributions of inferiority, but actively resist the process of subordination.

Cet article porte sur les pratiques d'alternance de langue chez de jeunes enfants d'origines culturelles et linguistiques diverses dans des classes de maternelle et de première année. L'auteur propose que l'emploi que font ces enfants de l'alternance de langue dépasse le besoin de soulagement du stress psycholinguistique ou de la liminalité, ce sentiment de vivre entre deux langues et deux cultures. Par le biais de récits construits à partir de données ethnographiques, l'auteur étudie le recours de ces jeunes à l'alternance de langue comme réaction aux forces dynamiques sociolinguistiques et sociopolitiques auxquelles ils étaient confrontés en salle de classe. L'alternance de langue a permis à ces élèves de répondre à leurs besoins linguistiques et littéraires, d'affirmer leur identité et d'échapper aux tendances assimilatives découlant du manque d'intégration de leur langue maternelle. De plus, les résultats appuient l'affirmation de Cummins (2001) selon laquelle les élèves n'acceptent pas passivement les attributions d'infériorité de la part des groupes dominants, mais qu'ils affichent une résistance solide au processus de subordination.

\section{Introduction}

International economic restructuring has had global and local affects. Globally, it has ensured (among other things) increased mobility of labor markets 
and cross-cultural contact (Burbules \& Torres, 2000; Cummins, 2005). Locally, students in North American elementary schools are more culturally and linguistically diverse than they have ever been (Obiakor, 2001). In the Canadian context, a significant number of children in elementary schools located in urban centers speak a first language (L1) other than English or French (Citizenship and Immigration Canada, 2003). Despite these changing demographics, researchers have noted a dearth of research about culturally and linguistically diverse (CLD) students in early childhood education (ECE) and disparity in providing for these students (Bernhard, Lefebvre, Chud, \& Lange, 1995; Toohey, 2000; Suárez-Orozco, 2001; Falconer \& Byrnes, 2003). Further, the limited scholarship about young children learning English as second language (ESL) has traditionally been methods-focused, with little produced from sociocultural and critical perspectives (Toohey). In contrast, this study contributes to the more recent growing body of work in earlyyears literacy research grounded in sociocultural theory as it informs early literacy (Bourne, 2001; Gee, 2001; Boyd \& Brock, 2004) and also draws on critical multiculturalism as an analytic lens (McLaren, 1994; Kincheloe \& Steinburg, 1997; May, 1999; Ladson-Billings, 2004).

Two basic tenets of sociocultural theory highlight its relevance and applicability to this research. The first "is that the mind is social in nature" (Boyd \& Brock, 2004, p. 4). The second tenet is that "language in use plays a central role in mediating our actions as humans.... Consequently, the uses of language in the context of interactions, and the various analytical ways of looking at that language become central when considering human learning" (p. 4). Literacy is conceptualized as a social practice and socially mediated. As such, coming to literacy is not exclusively about the acquisition of a code but also, and more importantly, about encountering a culture. Classroom literacy practices can, therefore, be understood as a particular set of cultural events. Thus it is imperative to examine critically what students appropriate as they encounter school literacy as well as the effect that this appropriation has on their identities. To this end, critical multiculturalism further informs an analysis of the literacy practices and events encountered by CLD students in their early-years classrooms and allows for an examination of what they appropriate as well as the effect that this appropriation has on their identities.

Critical multiculturalism as it relates to education is influenced by critical pedagogy, which "is the term used to describe what emerges when critical theory encounters education" (Kincheloe \& Steinburg, 1997, p. 24); critical theory is "especially concerned with how domination takes place, [and] the way human relations are shaped in the workplace, the schools and everyday life" (p. 23). As such, critical pedagogy explores "how pedagogy functions as a cultural practice to produce rather than merely transmit knowledge within asymmetrical relations of power that structure teacher-student relations" 
(Giroux, 1992, in Sleeter \& Bernal, 2004, p. 241, original emphasis). The influence of critical pedagogy has helped link multicultural education with wider socioeconomic and political inequality. This link has historically been absent from discussions about and conceptualizations of multiculturalism and multicultural education (May, 1999).

The above-mentioned framing informs the year-long ethnography (Iannacci, 2005) that is reported on in this article. The study addresses gaps in the provision of appropriate education for CLD children in two kindergarten and two grade 1 classrooms by examining the following guiding questions. What are the literacy practices and events CLD students encounter in earlyyears classrooms? How does this "lived" curriculum facilitate and constrain cultural and linguistic assimilation and acculturation as CLD students acquire ESL? What part does it play in the negotiation of their identities?

The study uses critical narrative research (CNR) as an expression of ethnography to address these key questions. CNR is an emerging genre that frequently border-crosses a variety of theoretical orientations and borrows from ethnographic traditions while remaining aware of its colonial underpinnings (Clair, 2003). CNR research is concerned with culture, language, and participation as issues of power in need of critique with the intent of changing the direction of social justice (Moss, 2004).

Data collection consisted of two phases of observation throughout a school year in four early-years classrooms in two schools. During both phases of the research, the researcher engaged in overt participant observation (Wallen \& Fraenkel, 2001, p. 436) and thus ensured that research participants knew that they were being observed. Once university, school board, principal, and teacher approvals and permissions to conduct research had been secured, preliminary briefing sessions with students took place. The briefing introduced and made explicit the researcher/researcher's role in the classroom and clarified the information and permission forms/letters that students took home to their parent(s) or guardian(s). The letters clearly stated the nature of the research as well as the role of the researcher. Letters and permission forms were written in the CLD students' first language to ensure that their parents fully understood the study and, therefore, were translated into Albanian, Arabic, Serbo-Croatian, Spanish, and Turkish. All the remaining students in the classrooms received letters in English in order to inform their parents or guardians of the researcher's presence and role in their child's classroom as well as the nature of the study.

School documents, field notes, photographs, and children's work were collected during fieldwork. Interviews with teachers, parents, school board personnel, and students were also conducted throughout the year. These multiple forms of data were used to construct narratives that were then deconstructed through reflection about and a distancing from the relations of power that informed what was observed. Literacy events, practices, themes, 
and salient issues that emerged from the narratives were discussed after they had been contextualized and interrogated for inconsistencies and contradictions. Reconceptualized understandings about the data were subsequently developed as a result of this "threefold mimesis" (Ricoeur, 1992, in Herda, 1999 , p. 76). This analytic-interpretive process, which began with the archiving, sorting, developing, and rereading of field texts (Clandinin \& Connelly, 2000), allowed for the juxtaposition and identification of similarities and/or contrasts in data, which subsequently revealed patterns, themes, narrative threads, and tensions. Data relevant to key issues being examined in this article from the larger study are presented as a way of demonstrating and exploring these issues.

One of the key issues that emerged as guiding questions explored in the larger study was the nature of CLD students' code-switching (CS) in school. CS or language-switching may be defined as "the use of two languages simultaneously or interchangeably" (Valdes-Fallis, 1977, in Fránquiz \& De La Luz Reyes 1998, p. 215) and identified as "a common discourse strategy for bilinguals" (García, 1983, p. 133). ${ }^{1}$ Although CS is a contested term, definitions that inform this article are commensurate with Crystal's (1997) exploration of the complex network of interactions and rationales that influence when and why CS is used and his assertion that speakers may indeed switch to a different language despite the fact that interlocutors would prefer another. Cromdal (2004), examining CS in children's disputes in school, observed them code-switching into a language that their communicative partner did not know in order to limit their opponent's argumentative resources during a conflict. As such, CS may be performed with specific intent and may or may not occur between two or more bilinguals who speak the same language, based on desired effect.

How CS is conceptualized and explored in this article, therefore, focuses on the influence of context in relation to children's CS and the power relations that influence why and how CS occurs in this context. These concerns are commensurate with sociocultural and critical concerns and perspectives that move beyond deficit-oriented psycholinguistic definitions and understandings of CS that have historically overemphasized psycholinguistic triggers as compensating for difficulties in sentence planning and speech fluency (Myers-Scotton, 1993), despite the fact that such instances account for only a small proportion of CS (Crystal, 1997). Zantella (1997) argues that past research has also focused on specific features of the CS that occurs between bilinguals rather than on the context that gives rise to bilingualism or on explicating how bilinguals subsequently learn to switch.

This is not to say that more recent context-focused research has been fully satisfying either. This research has tended to construct the liminality ${ }^{2}$ that CLD students negotiate when they enter school as disorienting as well as disruptive to identity (Anzaldúa, 1993, in Fránquiz \& De La Luz Reyes, 1998) 
without fully considering how CLD students use CS in response to relations of power specific to school systems and as a way of negotiating the acquisition of cultural and linguistic capital. Bourne (2001), however, notes,

Children learn the distinction between legitimate and illegitimate discourses in the school system as they learn their "basic skills" ... They learn what to reveal about their lives; which language counts, and which does not; and they learn to find ways of coping with this knowledge, of living with dignity.... children are not simply passive pawns in socialisation processes. (p. 104)

Findings from this research corroborate Bourne's observations and reassert the positioning of bilingual children's CS as serving multiple functions and mediated by social and linguistic contexts and relations of power. Thus this article examines how CLD students used CS as a strategy to negotiate liminality and their identities, to resist assimilation, and ultimately to develop their bilingualism further by critically analyzing the effect of the linguistic and social environment of the school on their CS and on the identity options (Cummins, 2005) made available to them in their early-years classrooms. The effect of the sociolinguistic, sociopolitical context on these classrooms is at the forefront of this analysis. Alternative understandings about how CLD students are provided for in English instruction ECE are then offered.

The following data present teachers' constructions of first languages, the linguistic classroom space CLD that students encountered, and descriptions of CLD students' use of CS in these spaces. The data are presented, discussed, and finally used to extend reconceptualized understandings of literacy instruction that address how CS can be fostered as a pedagogic resource in early-years classrooms.

\section{Teachers' Constructions of L1}

Some of the teachers in my study viewed first languages as barriers to academic achievement, and implicit messages about the detrimental effects of first languages for ESL learning were present in their beliefs and practices as well as in the status and role that first languages had in their classrooms. Connie (grade 1 teacher, all names are pseudonyms) had this to say.

I think ... you've got the student who can't even speak the language or you've got the student who can speak the language but probably you know, it's holding him back in their reading abilities.

Although Pat (kindergarten teacher) firmly believed in first-language maintenance, she held that confining CLD students to using it at home was less confusing for them, and so she made a point of somewhat discouraging first-language use at school except when it could not be avoided. 
Pat: I've had kids speaking Arabic in the room and I'll say to them, "Arabic at home, English at school." If they are really, really confused, I will ask one to translate for another and to communicate. Usually a helper will come down. I might get [someone] to translate for [students]. Me: So it's not a hard and fast rule.

Pat: No, not a hard and fast rule. No. I mean if they can't get by any other way but in Arabic, that's fine, and if they are playing with each other then I don't mind.

Me: Why do you prefer first language at home and English at school? Pat: Well, I just think that for the 4-year-old child it's probably a little easier to organize that in their little mind you know of, [in the child's mind] "OK, I'm at home and this is the rules and consistency and the structure here and there's a whole other language that goes with that." Plus that's the language that their parents speak and whatnot, and then if we come to school, you know "English only at school." But you can't ever go with complete hard and fast.

Although Pat's "English at school, first language at home" rule was by no means "hard and fast," bilingual volunteers and children were never asked to speak in their first language when the opportunity arose in any of my visits to the classroom.

Sarah (grade 1 teacher) believed that learning English while maintaining and/or developing a first language was confusing for CLD children and so encouraged parents to use English at home in addition to their first language.

I think the language ... we have a really high ESL population in this school and in this class. I have 11 kids that go out to ESL every other day or so and that's a little bit tough too because you don't wanna start something when they're not in the room. And, also, just because ... they don't speak the same languages at home. This is the only time that some of these kids are speaking English and you see that.

\section{The Classrooms, Two CLD Students, and Their CS}

Despite some of the teachers' rhetorical encouragement of children's first languages and their belief in its importance, there were few instances when they set conditions or organized instruction for students to use or draw on their first language. The primary focus was for the most part learning English. When first languages were accessed in the schools, they often functioned as an attempt at good public relations. Both schools, for example, displayed multilingual environmental print in the form of welcome signs in the main entrances written in languages spoken by members of the school community, which appeared to be for the benefit of parents. Paula (an ESL teacher) commented, 
This school's really great because they have put up huge posters in various languages, and it's nice for the kids to actually see. I think it says welcome, and for the kids to walk through and actually see their own language written is lovely.

Cindy posted a "Language Map" outside her classroom with the word welcome written in a variety of languages. Beyond these examples, no other multilingual environmental print was used in the classrooms I researched, nor were first languages used as resources. During one of my first visits to Sarah's class, the students were finishing an All About Me book. None of the writing frames Sarah provided asked students about their cultural or linguistic backgrounds, but rather focused on which hand they wrote with and their future careers.

There were some exceptions to this lack of L1 use. Michelle (an ESL teacher) often began her ESL sessions by picking up the children from their classrooms and greeting them with a word she had learned in their languages or drawing on their L1 knowledge. Beginning the sessions in this manner seemed to give the children permission to code-switch into their L1 when they needed or wanted to. The following narrative crafted from field notes depicts the environment that Michelle fostered and the subsequent effect it had on a CLD student named Inés and her classmates. It is followed by Akil's story, a student committed to demonstrating his first language proficiency and pride in a classroom context that did not always support his desire to do so.

Uno, Dos, Tres, Cuatro

Inés attended senior kindergarten at Elmwood (pseudonym) after arriving in Canada in February 2002 from Argentina. She began receiving ESL support at the beginning of her grade 1 year. Most of her utterances were in English but she would code-switch into Spanish when she did not have the English vocabulary to name an item (e.g., hielo for icicles) or to demonstrate her ability to speak her first language. The first time I noticed Inés doing this was during an ESL session in early October that is described below. Michelle's encouragement of first-language use seemed to foster a comfort level that allowed for the switches. Inés also participated a great deal more often in the ESL sessions than during whole-class instruction in the regular grade 1 class. After the October session, I noticed that she began to enjoy teaching her classmates Spanish when the opportunity arose in her regular classroom. For example, as I read the class two Spanish and English bilingual booksHairs/Pelitos by Cisneros (1994) and Taking a Walk/Caminando by Emberley (1990) - Inés voluntarily sat in a chair right beside me in front of the class and happily translated words and sentences in the books into Spanish as her classmates repeated them (e.g., school/escuela). Throughout the year, some of her classmates would repeat words she taught them. I asked her how she felt 
about this after observing such an incident. She beamed and said, "It makes me happy." Inés enjoyed the bilingual books so much that she asked me for her own copies. I provided her with the books, and later, when I asked her if she was enjoying them, she said, "I'm reading with Mom. I learn to read in English and Spanish. It's good. I read with my sister first in Spanish, then in English. My mom says it's good." Inés also asked me for more letters in Spanish similar to the one I had sent home with her asking her parents for permission to include her in my study.

Michelle comes to the door to pick up Inés and other students learning ESL. She greets all of them and then looks directly at Inés, who is standing at the front of the line, and says "Hola." Inés smiles back at her and cheerfully responds, "Hola."

Michelle asks Inés if she would like to count all the children in Spanish to make sure everyone is present. Inés agrees and counts, "Uno, dos, tres, cuatro" as we make our way to the ESL room. Michelle echoes Inés, tells her she is taking Spanish lessons, and asks for her help in learning the language. She then asks other students if they would like to count their peers in their first language as we walk toward the ESL room.

Today is E day and Michelle delivers a lesson on short and long /e/ and on how to print the letter $E$. At the end of the lesson, Michelle asks the students to think of words that begin with $E$ and opens a picture dictionary to the $E$ page to aid them. Inés looks at the pictures carefully, but does not respond. Michelle points to a picture of an egg and says, "What's this?" Inés pauses thoughtfully and says, "Huevo." Michelle affirms her answer and adds, "Oh, in Spanish this is a huevo. In English it's called an egg." Inés repeats "Egg." Michelle asks her what letter it starts with and Inés replies "E." Michelle then takes a piece of paper and draws a picture of an egg and writes the letter $E$ under it. She then asks the students what letters should follow and with their collective help, continues to label her egg illustration. She then tells the students that they will also be drawing and labeling pictures of things that begin with $E$. She provides each of them with a picture dictionary to help with the task.

As I begin working with Inés, she points to an elephant and says, "Elefante." I repeat what she has taught me and point out how similar the word is in English: Elephant. She draws a picture of an elephant and as she finishes its ears, Michelle points to her picture and says, "This begins with $E$ as well, and you have two of them." Michelle tugs on her own ear lobe to give Inés a clue. Inés says, "Oreja," and we both affirm her response. Michelle adds, "In English it's called an ear." She then writes the word ear on Inés' sheet with an arrow pointing toward the ears on the elephant that Inés has drawn. Inés then points to the tusk on the elephant picture and says, "Colmillo." Once again I greet her response positively and repeat the word in English for her. Inés' friend Janna is seated next to her and is listening 
intently as she draws and labels $E$ items from the picture dictionary. Eventually, she also begins to name items in Albanian and then English. Occasionally, she thinks of other $E$ words in English on her own and then names them in Albanian.

Once the session is over, we escort the students back to the grade 1 classroom. I have a brief discussion with Michelle about what occurred and her willingness to let students use their first languages as resources. Michelle believes that it is "fair enough" to do so because they are learning English. She also recognizes that some of them have fairly well developed skills in both languages and wishes to draw on this.

I enter the classroom as the students prepare for snack and then recess. I open my notebook and begin recording what has just transpired. Inés wanders over to me and asks what I am writing. She asks me if she can write in my notebook. I hand it to her and she draws a picture of a man. I ask her who it is and she replies, "You." Underneath the picture she writes "Man" and "Hombre."

Akil

Akil, the youngest of two children in his Arabic-speaking family, was extremely proud of and generous about sharing his cultural and linguistic background with me. Akil's family had visited Lebanon before he began junior kindergarten. He remembered this time with great fondness and talked about friends and relatives. Akil even insisted that he was born in Lebanon, although his father and documents in his Ontario Student Record (OSR) attested to the fact that he was born in Canada. In November, Akil completed a frame sentence that Sarah had assigned that began, "When I wish upon a star I wish ..." by writing "I wish I was in Lebanon." On one of my first visits to the grade 1 class, Sarah asked Akil to let me see what he was wearing. Underneath his white turtleneck with a Canadian maple leaf was an olive t-shirt that read "I Love Lebanon." He smiled from ear to ear as he proudly showed it to me.

Akil enjoyed attending "Arabic school" on Sundays and was learning to recite the Suras (Quranic prayers) and the Arabic alphabet, which he shared with me. During one of our conversations, he said that speaking Arabic was one of his favorite things to do because it was his language. Although Akil was conscious of the fact that he spoke Arabic at home and English at school, he often traversed this observed rule in certain contexts (e.g., before morning circle or right before and after recess or lunch, as well as during book exchange in the library). He also took pleasure in teaching me various Arabic words and phrases during our ritual morning visit, which would begin when he would enter the classroom, search me out and immediately ask, "Can I read to you?" He then asked me to remember the Arabic words he had taught me the week before. After my test, he would read a leveled book to 
me. From time to time, he would ask to see some of the books I had shared with the class, some of which were bilingual and written in Arabic and English. He would flip through the pages eagerly and attempt to read them or ask me to read them to him again.

Akil's English oral proficiency was well developed, and he frequently participated during whole-class instruction or discussions, especially during the ESL sessions. Although Paula (Akil's ESL teacher) made many comments that expressed her belief about the importance of recognizing and fostering linguistic and cultural diversity, conceptualizations of her job as an ESL teacher did not reflect these beliefs.

I'm hoping that what we [ESL teachers] do is help the children access the curriculum, whether that be when they're beginners, giving them initial working vocabulary and as they get further on, helping them by adapting a program for them so they are able to be successful along with whatever the class is doing.

Her comments were also evident in her practice. I did not observe a single ESL session that drew on the students' linguistic or cultural backgrounds. In fact aside from the bilingual and multicultural books I read to the students, no bilingual books and a limited number of multicultural books were used in most of the classrooms.

As illustrated in the above narratives and descriptions of students, instances of CS were generally infrequent in the mainstream classrooms and tended to occur during transitions or during unofficial class time (indoor recess, before announcements, library visits, etc.). However, as the year progressed, many of the students felt comfortable enough with me to switch when they needed to and even more commonly when they wanted to demonstrate their L1 knowledge. In response to what I observed, I began planning experiences that attempted to access students' L1 knowledge. I did this when teachers voluntarily gave me instructional time. Sarah (grade 1 teacher) provided me with the most instructional time, which meant that I had more opportunities to respond to students' cultural and linguistic diversity in her classroom. Eventually, she scheduled a portion of the day for me to work with the class during my visits.

By January, I felt comfortable enough to ask Sarah if she would think about using multilingual environmental print in her classroom. She agreed, and I made color-coded multilingual labels in Spanish, Arabic, English, and Polish for objects and concepts that featured prevalently in her classroom (e.g., the chalkboard, windows, numbers, colors, etc). After this event, Sarah observed CLD students trying to teach their classmates how to pronounce the various words featured around the classroom. She also mentioned that CLD students seemed more comfortable talking in and about their first languages than previously. I made similar observations and in addition 
noted that CS was no longer occurring only during unofficial and transitional class times. At the end of the year, Sarah asked me for the materials and process I had used to organize the multilingual environmental print and said that she was looking forward to using it with future classes.

\section{Discussion}

Although some of the CS that Inés engaged in relieved psycholinguistic stress caused by vocabulary difficulty and the need to monitor and ensure comprehension and fluency (Clyne, 1967, in Saunders 1988; Myers-Scotton, 1993), more significant and prevalent about her and Akil's CS was that it was less a result of psycholinguistic factors than of the sociolinguistic dynamics that both students were negotiating. They used CS not only as a way of coping with the liminality (cultural and linguistic in-betweenness) they were experiencing and the linguistic demands of the predominantly monolingual classroom environment, but also as a way of capitalizing on their knowledge of official and unofficial discourses, and as such as a hybrid literacy practice (blending of primary and dominant languages and registers) that helped them negotiate socialization in the context of their classrooms (Manyak, 2002). This was especially evident in how Inés and Akil seemed to understand that it was acceptable to code-switch at certain times of the day and in specific places (e.g., during transitions and outside the official mainstream classroom).

The less perfunctory CS in which the students engaged created opportunities for them to bring their language and culture into the school context and to exert their identities. Inés' voluntary involvement in the shared reading of bilingual books, for example, and Akil's reciting of the Suras positioned their CS as a social indexing device (Myers-Scotton, 1993) that conjured up and/or indicated another identity apart from that of the dominant culture and language of the classroom. Akil and Inés were, therefore, able to remind their classmates and me of their Other identity, an identity that was often repressed and positioned as having little or no capital in their classrooms.

The complex and layered use of CS by Akil and Inés allowed them to create a hybrid "third space" (Bhabha, 1990, p. 220) or "borderland territory ... [a] physical and metaphorical space between school and home where children negotiate culturally appropriate ways of operating" (Gee, 1990, in Wilson, 2003, p. 296). This space is often formed in order to (re)construct a sense of personal and community identity and is "generated from necessity, at sites of struggle, or when existing spaces do not provide the necessary feeling of belonging" (p. 296). The students cultivated this space in response to the linguistic habitus, or accepted "common sense" (Bourne, 2001, p. 108), present in their classrooms informed by largely unquestioned discourses that promoted assimilationist orientations and fostered coercive relations of power. The linguistic habitus present in the classrooms (both mainstream 
and Paula's ESL classroom) was indicative of what Gogolin (1994) termed "monolingual habitus" (Bourne, p. 107) in that the dominance of English was taken for granted and viewed unproblematically. This corroborates Bourne's findings, which demonstrate that despite schools' large multi-ethnic populations, English is often assumed to be the language of literacy in them, thus rendering language an invisible issue that allows schools to function as if the mother tongue of all children were English. The lack of attention paid to accessing and capitalizing on students' L1 in most of the classrooms I observed, and the marginal role that students' L1 occupied in the classrooms, consistently demonstrated this monolingual habitus. Several notions instantiated practices that reinforced and furthered this monolingual habitus.

The linguistic mismatch hypothesis contends that "a home-school language switch will result in academic difficulties" (Cummins, 1991, p. 162) and has been used to argue for transitional bilingual education where initial instruction occurs in a student's first language. Ironically, this notion, coupled with a belief that students' English deficiencies necessitate maximum exposure to English characterized as the "insufficient exposure" hypothesis (p. 162) informed understandings of students' L1 use in many of the classrooms and was evident in interviews with teachers, particularly those conducted with Pat and Sarah. These notions were also manifest in the lack of attention paid to linguistic diversity in literacy curricula.

Although Cummins (1991) and other researchers such as Yeung, Marsh, and Suliman (2000) have demonstrated the inadequacy of these hypotheses and the benefits of L1 maintenance and development during L2 acquisition, both hypotheses continue to be present in the mindset of some educators. Part of the reason why these understandings remain dominant is the fact that for some, it is counter-intuitive to view the simultaneous acquisition of two languages as beneficial rather than confusing and contributory to CLD students' academic difficulties (Crawford, 1992). Yeung et al. attribute the pervasiveness of these notions to behaviorism and behavioral psychology: "The behaviorists' emphasis on habit formation implies that a language other than English has to be unlearned before new, desirable habits in the target language of English can be successfully formed" (p. 1003). Findings from their large-scale study contradict such notions, demonstrate links between academic achievement and home-language maintenance, and corroborate Cummins' linguistic interdependence principle, which stipulates that if effective instruction that promotes proficiency in a student's first language is present, transfer of this proficiency to a student's second language will occur "provided there is adequate exposure" to the student's L2 as well as "adequate motivation to learn" it (p. 166). In other words, instruction that promotes students' L1 also develops “a deeper conceptual and linguistic proficiency that is strongly related to the development of literacy in the majority language" (p. 166) because there is "an underlying cogni- 
tive/academic proficiency which is common across languages.... [that] makes possible the transfer of cognitive/academic and literacy-related skills across languages" (pp. 166-167). Furthermore, even more relevant to this study is the idea that an additive orientation toward first language incorporation is socially, psychologically, and emotionally beneficial to students, which contests subtractive forms of schooling that have "essentially amounted to an assault on [CLD students'] personal identities" (p. 164).

It is once again important to point out that, "even within a monolingual school context, powerful messages can be communicated to students regarding the validity and advantages of primary language development" (Cummins, 2001, p. 212). An "additive orientation does not require the actual teaching of the minority language" because "educators ... communicate to students and parents in a variety of ways the extent to which the minority language and culture are valued within the context of the school" (Cummins, 1986, p. 26). Keeping this in mind, it is disconcerting to note that aside from the welcome and hello posters, little multilingual environmental print or attention to first-language incorporation was evident in the schools and classrooms. Therefore, it is crucial to question and be concerned about the message that children and parents receive from schools about the importance and value of first languages. Wong Fillmore (2000) elucidates the dilemma that CLD children face.

The inability to speak English in school is a handicapping condition in many communities, particularly in places that have no programs designed to help children who are limited in English proficiency.

Children in such situations, irrespective of background or age, are quick to see that language is a social barrier, and the only way to gain access to the social world of the school is to learn English. The problem is that they also come to believe that the language they already know, the one spoken at home by their families, is the cause of the barrier to participation, inclusion, and social acceptance. They quickly discover that in the social world of the school, English is the only language that is acceptable. The message they get is this: "The home language is nothing; it has no value at all." If they want to be fully accepted, children come to believe that they must disavow the low status language spoken at home. (pp. 207-208)

Although research by Wong Fillmore (2000) and Yeung et al. (2000) is important because it demonstrates the benefits of home-language maintenance and reinforces the need for an additive orientation with respect to linguistic incorporation in schools, it is essential to explore what remains unquestioned. Despite all the literature the authors cite and the efforts they exert in demonstrating the importance of home-language maintenance, there is no elucidation of why additive orientations toward linguistic incorpora- 
tion remain largely unsupported and underdeveloped in schools. Yeung et al.'s (2000) comments about the pervasiveness of behaviorism seem insufficient to clarify this phenomenon. The authors do not question why there is still a struggle to promote additive orientations in countries as linguistically diverse as Canada and the United States, nor do they consider macro factors that affect interactions that teachers and students encounter in schools. This is especially important to consider when we specifically examine the extent of language loss in the Canadian context. Helms-Park (2000) reminds us that

Some researchers predict that intergenerational loss of ethnic groups languages in Canada ... will culminate in complete or near-complete linguistic assimilation among all but newly arrived immigrant groups. Language attrition in the second and third generations among ethnic groups is undoubtedly a reality in Canada, as is indicated by analyses of census and survey data. (p. 128)

From an international perspective, data also reassert what researchers such as Philipson (1998) and Skutnabb-Kangas (2000) examine in terms of how and why schools have contributed to the "linguistic (and cultural) genocide" (p. $x$ ) that many countries throughout the world are currently experiencing. Skutnabb-Kangas states, "Education through the medium of majority languages or colonial languages has been the most powerful assimilating force for both indigenous children and immigrant/refugee minority children, thus likewise having a homogenizing function" (pp. 201202). She argues that,

Genocide happens equally effectively when a child is psychologically (and structurally) prohibited from speaking (and wanting to speak) her own language, and is psychologically transferred to another group, made to want to identify with a dominant group instead of, rather than in addition to her own. (p. xxxiii)

An extensive exploration of the state of minority languages in several countries and a close examination of linguistic human rights (LHRs) indicts countries such as Canada for perpetuating linguistic colonialism and genocide through its education system. Skutnabb-Kangas (2000) explores how coercive relations of power are shaped and furthered by international economic restructuring and a belief that a common international language and "global core curriculum" (p. 466) are needed for globalization. The shift toward universal literacy and universal approaches to education devoid of policy-putting basic human rights rather than economic growth in focusis evident in many educational systems around the world including Canada. In this context, "deficiency-based models ... are used ... [to] invalidate the linguistic and cultural capital of minority children and their parents and communities.... [and] make the resources of dominated groups seem hand- 
icaps or deficiencies, instead of valued and validated non-material resources" (p. x). Globalization has stressed homogenization and has acted as a "killing" agent of diversity (p. xi). This has partly been accomplished through the unofficial inauguration of English as the language of globalization.

I am not suggesting that the effects of globalization were explicitly evident in the interviews that I conducted or definitively correlated to the status of first languages in the classrooms or the literacy practices and events shaped by this status. However, it is important to recognize how issues with respect to first language maintenance in the multilingual classrooms that I observed were rendered invisible and inconsequential under the premise that English was an official and targeted language, and therefore to be taken for granted. The lack of attention that first languages received mirrored the governing texts that shape literacy instruction in the classrooms, namely, The Ontario Language Curriculum, Grades 1-8 (Ontario Ministry of Education and Training, 1997) and The Ontario Curriculum: The Kindergarten Program, 1998 (Ontario Ministry of Education and Training, 1998). Both documents are steeped in and reflect the discourse of globalization, and neither actually addresses how first languages are to be understood or incorporated into literacy curricula. Rather, these documents focus on elucidating the role of the school as exclusively assistive to the ESL learning process. The absence of any mention of the importance of first languages and the cultivation of opportunities for these languages to be accessed and allowed for is problematically noticeable and influential.

Ironically, the reassertion of English as privileged linguistic capital and as the reigning language of globalization was occurring in classrooms that had never been so culturally or linguistically diverse or so reflective of the growing global mobility that is emblematic of globalization. In this context, first languages were at best dealt with ambivalently and complacently and at worst, viewed anxiously and treated as impediments to the achievement of monolingual literacy curricula.

To a certain extent, these CLD students' use of CS enabled them to address their language and literacy needs, assert their identities (despite the constrictive nature of the monolingual classroom context), and somewhat defy the subtractive and assimilative orientations that they experienced with respect to the lack of incorporation of their first languages. In this regard, these CLD students affirmed Cummins' (2001) assertion that they do not passively accept dominant group attributions of their inferiority, but rather actively resist the process of subordination.

\section{Implications}

Multilingual literacy practices and fostering literacy events that make the most of students' linguistic resources are vitally important in addressing the 
monolingual habitus and assimilative nature of schooling. Multilingual literacy can be fostered in classrooms operating in a multiliteracies framework in several ways. Some of the following suggestions have been adapted and extended from Herrell and Jordan (2004). First, it is essential to identify accurately the languages spoken by students. It must be noted, however (as witnessed throughout my research), that school records must be understood as fallible. The processes by which schools gather data and the conditions that parents learning ESL encounter during initial information-gathering meetings with school officials can create conditions that ensure inaccuracies. A teacher would do well to ask students, their older sisters and brothers (if any), and parents about first languages spoken at home.

Once students' first languages have been identified, teachers can create multilingual environmental print consisting of common items (e.g., blackboard, window, etc.) and concepts (e.g., colors, numbers) found in their classrooms. Various Web sites can be used to translate English words into various languages. Whenever possible, involve students in writing and placing multilingual environmental print in the classroom and provide opportunities for them to speak the words in their first languages. During this process, it is also valuable to make cognates explicit while asking students to do the same. Multilingual posters, alphabets of the languages spoken by class members, the names of children in their own language and in English, product packaging with various languages written on it, common phrases in various languages, and work done by students in their L1 can also be posted or brought into the classroom to create a multilingual print environment (Schwarzer, Haywood, \& Lorenzen, 2003).

Teachers can also provide students with texts written in both English and home languages for use in read-aloud, independent, and home reading programs. When using bilingual books during shared reading sessions, students who speak the language the book is written in can sit beside the teacher and either read what is written in their first language or translate what the teacher has read in English. If they translate, the teacher can follow the text written in their L1 and look for words that resemble what they have read while pointing these words out to the student and the rest of the class. Most of the students in my study were eager to participate in this shared readaloud. In fact this configuration of practice arose as a result of Inés' desire to demonstrate her knowledge of Spanish to her classmates and may be completely credited to her. She asked to sit next to me and showed me how to incorporate her into the shared reading that I was conducting with a Spanish-English bilingual book. I replicated the practice with other students who also became my co-teachers and consequently were viewed as classmates who possessed valuable assets that became explicit and instructionally relevant. 
Literacy instruction can also be organized so as to enable students to create their own bilingual books or texts. Although none of my participants had an opportunity to create a complete bilingual narrative, some of them wrote and drew various "identity texts" (texts in which CLD students have invested their identities and reflect who they are; Cummins, 2005). These texts mirrored the structure of the bilingual books to which they were being exposed and could have been extended into complete books with the help of parents, siblings, or volunteers. Inés, for example, drew a picture of me after I had read her a Spanish-English bilingual book. She labeled the picture Man/Hombre.

In order to cultivate heteroglossia (Bakhtin, 1981) and foster conditions in classrooms that create a "third space" (Bhabha, 1990), acceptance of CS must be made explicit and its viability as a pedagogic resource recognized. Montague and Meza-Zaragosa (1999) demonstrated the benefits of eliciting responses in children's first languages. Classrooms that regularly use this practice establish conditions that allow students learning ESL to renegotiate their less-than and deficient school identities by showcasing and instructionally drawing on the linguistic resources that they possess. In these classrooms, children whose first language is English begin to understand that their often quiet ESL classmates have fully developed thoughts that they can express in their L1, although they are simply not as proficient in the privileged code. Incidents that require CLD students to use their classmates' L1 to respond to a question further reinforce this understanding.

Fránquiz and De La Luz Reyes (1998) also advocate for the recognition of CS as a pedagogic resource and demonstrate its benefits for CLD children in English-language classrooms that often make "English ... a prerequisite for learning.... [and limit] students' opportunities to use their store of cultural and linguistic knowledge and experiences as resources" (p. 211). The authors describe various "acts of inclusion" that address the key question that many teachers have: "If I am not fluent in the languages my students speak, how can I effectively teach English language arts to a linguistically diverse class?" (p. 212). The various acts of inclusion or vignettes from classroom practice that the authors describe showcase teachers eliciting students' responses in their first languages, which ultimately provide "an opportunity for a linguistically diverse learner to be a competent member and more 'expert other' ... within an English lesson" (p. 213, citing Vygotsky, 1978). Many of the vignettes mirror some of the events I observed in Uno, Dos, Tres, Cuatro, as well as interactions that I had with students who capitalized on their L1. Central to these vignettes is the negotiation of the literacy curriculum. When CS is allowed, teachers may move in and out of English throughout their interactions and lessons in order to draw on their students' L1. Improvisation and situated decision-making may allow them to engage instructionally and include CLD students while using the L1 to support L2 learning. More 
important, students' identities may become valued and pronounced in the classroom as opposed to being hidden and silenced. Delpit (2002) believes that CS can lower socioaffective filters that impede second-language learning and argues that "since language is one of the most important expressions of identity, indeed, 'the skin that we speak,' then to reject a person's language can only feel as if we are rejecting him [or her]" (p. 47). Informed understandings about and practices that encourage CS can, therefore, perhaps improve learning conditions for second-language learning and learners while creating "curriculum that apprises the students of their intellectual legacy" (p. 41) and allows them to be and become who they are.

Teachers can develop many other practices to access and instructionally draw on CLD students' L1. Cummins (2001) suggests that "each day, one student can be invited to bring in a word that is particularly meaningful to him or her and all students in the class can learn this word and talk (in English) about its meaning and cultural connotations" (p. 212). Interestingly, one of the parents I interviewed throughout this study mentioned similar practices when discussing what might have helped her daughter feel welcomed and accepted in school. Teachers can also generate a list of words that are commonly used and important to classroom life (e.g., bathroom, coats, lunch, etc.) and keep the list accessible. Again, the Internet can serve as a translation resource. When CLD parents volunteer to work in classrooms, teachers can make explicit how accepted CS is and encourage them to codeswitch or engage in prolonged conversations with students who share their L1. Parent volunteers can also be instructed to help students who share their L1 and C1 create dual-language books and other identity texts.

These suggestions are by no means all-encompassing. Ultimately, multilingual literacy practices should continue to evolve and be recognized as sound pedagogy that extends classroom language barriers, increases the status of students' L1, and ultimately opens up available identity options for CLD students in schools.

\section{Conclusion}

Much as I want to believe that these practices can somehow combat the linguistic and cultural hegemony I observed throughout my study, I know that this is overly optimistic and impossible. I also know that such practices may be dismissed by critical multiculturalists as window dressing and not really different from the public relations of the friendly multilingual welcome signs present in the halls of the schools that participated in this study. When I reflect on the deficit constructions of first languages and on the taken-for-granted dominance of English over CLD children, I am fully aware that multilingual, multicultural literacy practices are in themselves inadequate to counter the assimilation that these CLD students were negotiating and sometimes resisting. 
I also know that critical educators have been "pilloried for an inability to relate the critical theory they espouse to actual multicultural policy and practice" (May, 1999, p. 4). Therefore, there is a strong urgency to conceptualize thoughtfully and use practices that respond to issues to which critical educators are sensitive in full knowledge that the proposals may be inadequate. When I reflect on an interview I had with a parent, I cannot help but think that some of the practices I have outlined and have put in place in the classrooms that I researched have not been done in vain.

It cannot be overemphasized that she can feel if other children appreciate her language and her background because the other thing which I noticed was, my children were kind of embarrassed to be who they are. Because it wasn't cool to be different. It's never cool to be different ... But definitely it will help having [my daughter] share something in her language and somebody remembers that word and when they say it to her, I think it will be just great.

\section{Notes}

${ }^{1}$ Although I recognize and concur in broader conceptualizations of CS that include register- and dialect-switching, in this article I focus on the CS that occurs between two languages.

${ }^{2}$ An in-betweenness. A sense of living in the middle of two languages and cultures.

\section{The Author}

Luigi Iannacci has taught mainstream and special education in a range of elementary grades in Ontario. He is an assistant professor at Trent University. His research interests include first- and second-language and literacy acquisition, critical multiculturalism, and critical narrative research methodology. He is the current President of the Language and Literacy Researchers of Canada (LLRC).

\section{References}

Bakhtin, M.M. (1981). The dialogic imagination: Four essays. Austin, TX: University of Texas Press.

Bernhard, K., Lefebvre, M.L., Chud, G., \& Lange, R. (1995). Paths to equity: Cultural, linguistic and racial diversity in Canadian early childhood education. Toronto, ON: York Lanes Press.

Bhabha, H. (1990). The third space: An interview with Homi K. Bhabha. In J. Rutherford (Ed.), Identity: Community, culture, difference (pp. 207-221). London: Lawrence \& Wishart.

Bourne, J. (2001). Discourses and identities in a multi-lingual primary classroom. Oxford Review of Education, 27(1), 103-114.

Boyd, F.B., \& Brock, C.H. (2004). Constructing pedagogies of empowerment in multicultural and multilingual classrooms: Implications for theory and practice. In F.B. Boyd, C.H. Brock, \& M. S. Rozendal (Eds.), Multicultural and multilingual literacy and language: Contexts and practices (pp. 1-11). New York: Guilford Press.

Burbules, N.C., \& Torres, C.A. (2000). Globalization and education: An introduction. In N.C. Burbules \& C.A. Torres (Eds.), Globalization and education: Critical perspectives (pp. 1-26). New York: Routledge.

Cisneros, S. (1994). Hairs/Pelitos. New York: Drangonfly Books.

Citizenship and Immigration Canada. (2003). Facts and figures: Immigration overview. Retrieved July 21, 2005, from: http://www.cic.gc.ca/english/pub/facts2003/permanent/6.html 
Clair, R.P. (2003). The changing story of ethnography. In R.P. Clair (Ed.), Expressions of ethnography: Novel approaches to qualitative methods (pp. 3-28). Albany, NY: SUNY Press.

Clandinin, D.J., \& Connelly, F.M. (2000). Narrative inquiry: Experience and story in qualitative research. San Francisco, CA: Jossey-Bass.

Crawford, J. (1992). Hold your tongue. Bilingualism and the politics of English only. New York: Addison-Wesley.

Cromdal, J. (2004). Building bilingual oppositions: Code-switching in children's disputes. Language in Society, 33(1), 33-58.

Crystal, D. (1997). The Cambridge encyclopedia of the English language. Cambridge, UK: Cambridge University Press.

Cummins, J. (1986). Empowering minority students: A framework for intervention. Harvard Educational Review, 56, 18-36.

Cummins, J. (1991). Language development and academic learning. In L. Malave \& G. Duquette (Eds.), Language, culture and cognition: A collection of studies in first and second language acquisition (pp. 161-175). Clevedon, UK: Multilingual Matters.

Cummins, J. (2001). Negotiating identities: Education for empozerment in a diverse society (2nd ed.). Los Angeles, CA: California Association for Bilingual Education.

Cummins, J. (2005, April). Diverse futures: Rethinking the image of the child in Canadian schools. Paper presented at the Joan Pederson Distinguished Lecture Series, University of Western Ontario.

Delpit, L. (2002). No kinda sense. In L. Delpit \& J.K. Dowdy (Eds.), The skin that we speak: Thoughts on language and culture in the classroom (pp. 31-48). New York: New Press.

Emberley, R. (1990). Taking a walk: A book in two languages: Caminando: Un libro en dos lenguas. Boston, MA: Little, Brown.

Falconer, R.C., \& Byrnes. D.A. (2003). When good intentions are not enough: A response to increasing diversity in an early childhood setting. Journal of Research in Childhood education, $17,188-200$.

Fránquiz, M.E., \& De la Luz Reyes, M. (1998). Creating inclusive learning communities through English language arts: From chanclas to canicas. Language Arts, 75, 211-220.

García, E.E. (1983). Early childhood bilingualism, with speficic references to the Mexican-American child. Albuquerque, NM: University of New Mexico Press.

Gee, J.P. (2001). A sociocultural perspective on early literacy development. In S.B. Neuman \& D.K. Dickinson (Eds.), Handbook of early literacy research (pp. 30-42). New York: Guilford Press.

Helms-Park, R. (2000). Two decades of heritage language education. In C. Teixeira \& V.M.P. Da Rosa (Eds.), The Portuguese in Canada: From the sea to the city (pp. 127-145). Toronto, ON: University of Toronto Press.

Herda, E.A. (1999). Research conversations and narrative: A critical hermeneutic orientation in participatory inquiry. London, UK: Praeger.

Herrell, A., \& Jordan, M. (2004). Fifty strategies for teaching English language learners (2nd ed.). Upper Saddle River, NJ: Pearson, Merrill, Prentice Hall.

Iannacci, L. (2005). Othered among others: A critical narrative of culturally and linguistically diverse (CLD) children's literacy and identity in early childhood education (ECE). Unpublished doctoral disseration, University of Western Ontario.

Kincheloe, J., \& Steinburg, S. (1997). Changing multiculturalism. Philadelphia, PA: Open University Press.

Ladson-Billings, G. (2004). New directions in multicultural education. In J. Banks \& C. McGee Banks (Eds.), Handbook of research on multicultural education (2nd ed., pp. 50-68). San Francisco, CA: Jossey-Bass.

Manyak, P.C. (2002). "Welcome to Salon 110": The consequences of hybrid literacy practices in a primary-grade English immersion class. Bilingual Research Journal, 26, 421-442. 
May, S. (1999). Introduction: Towards critical multiculturalism. In S. May (Ed.), Critical multiculturalism: Rethinking multicultural and antiracist education (pp. 1-41). Abingdon, UK: Falmer Press.

McLaren, P. (1994). White terror and oppositional agency: Towards a critical multiculturalism. In D.T. Goldberg (Ed.), Multiculturalism: A critical reader (pp. 45-74). Cambridge, MA: Blackwell.

Montague, N.S., \& Meza-Zaragosa, E. (1999). Elicited response in the pre-kindergarten setting with a dual language program: Good or bad idea? Bilingual Research Journal, 23, 289-296.

Moss, G. (2004). Provisions of trustworthiness in critical narrative research: Bridging intersubjectivity and fidelity. Qualitative Report, 9, 359-374.

Myers-Scotton, C. (1993). Dueling languages: Grammatical structure in codeswitching. Oxford, UK: Oxford University Press.

Obiakor, F.E. (2001). Research on culturally and linguistically diverse populations. Multicultural Perspectives, 3(4), 5-10.

Ontario Ministry of Education and Training. (1997). The Ontario curriculum grades 1-8: Language. Toronto, ON: Queen's Printer for Ontario.

Ontario Ministry of Education and Training. (1998). The Ontario curriculum: The kindergarten program, 1998. Toronto, ON: Queen's Printer for Ontario.

Philipson, R. (1998). Globalizing English: Are linguistic human rights an alternative to linguistic imperialism? Language Sciences, 20(1), 101-112.

Ricoeur, P. (1992). Oneself as another. Chicago, IL: University of Chicago Press.

Saunders, G. (1988). Bilingual children: From birth to teens. Philadelphia, PA: Multilingual Matters.

Skutnabb-Kangas, T. (2000). Linguistic genocide in education-Or worldwide diversity and human rights? Mahwah, NJ: Erlbaum.

Sleeter, C.E., \& Bernal, D.D. (2004). Critical pedagogy, critical race theory, and antiracist education. In J.Banks \& C. Banks (Eds.), Handbook of research on multicultural education: Implications for multicultural education (2nd ed., pp. 240-258). San Francisco, CA: Jossey-Bass.

Schwarzer, D., Haywood, A., \& Lorenzen, C. (2003). Fostering multiliteracy in linguistically diverse classroom. Language Arts, 80, 453-460.

Suárez-Orozco, C. (2001). Afterword: Understanding and serving the children of immigrants. Harvard Educational Review, 71, 579-589.

Toohey, K. (2000). Learning English at school: Identity, social relations and classroom practice. Clevedon, UK: Multilingual Matters.

Wallen, N.E., \& Fraenkel, J.R. (2001). Educational research: A guide to the process. San Francisco, CA: Erlbaum.

Wilson, A. (2003). Researching in the third space: Locating, claiming and valuing the research domain. In S. Goodman, T. Lillis, J. Maybin, \& N. Mercer (Eds.), Language, literacy and education: A reader (pp. 293-308). Staffordshire, UK: Trentham Books.

Wong Fillmore, L. (2000). Loss of family languages: Should educators be concerned? Theory into Practice, 39, 203-210.

Yeung, A.S., Marsh, H.W., \& Suliman, R. (2000). Can two tongues live in harmony: Analysis of the national education longitudinal study of 1988 (NELS88): Longitudinal data on the maintenance of home language. American Educational Research Journal, 37, 1001-1026.

Zantella, A.C. (1997). Growing up bilingual: Puerto Rican children in New York. Oxford, UK: Blackwell. 